\title{
Florida Fresh: Summer Squash ${ }^{1}$
}

\author{
Claudia Peñuela $^{2}$
}

\section{Nutrition Facts}

\section{Florida's Summer Squash are:}

$\checkmark$ High in vitamin C. Vitamin C helps to heal cuts and keeps teeth and gums healthy.

$\checkmark$ High in vitamin A when left unpeeled. Vitamin A aids in normal vision, healthy skin, and protects against infections.

$\checkmark$ A good source of vitamin $B_{6}$ which helps us metabolize protein.

$\checkmark$ Supplier of folate. Folate produces red blood cells and reduces a woman's

risk of having a baby with certain brain or spinal cord birth defects.

$\checkmark$ Supplier of potassium which helps to control blood pressure.

$\checkmark$ Naturally free of fat, cholesterol, and low in sodium.

Note: Squash are divided into summer squash and winter squash. Florida produces more summer squash, including zucchini (part of the squash family) along with yellow.

\begin{tabular}{|c|c|}
\hline \multicolumn{2}{|l|}{ amount per Serving } \\
\hline \multirow[t]{2}{*}{ Calorles 18} & \multirow{2}{*}{$\begin{array}{c}\text { Calorles from Fat } 2 \\
\text { \% Dally Value* }\end{array}$} \\
\hline & \\
\hline \multicolumn{2}{|l|}{ Total Fat $0 \mathrm{~g}$} \\
\hline Saturated Fat 0g & $0 \%$ \\
\hline \multicolumn{2}{|l|}{ Trans Fat } \\
\hline \multicolumn{2}{|l|}{ Cholesterol Omg } \\
\hline \multicolumn{2}{|l|}{ Sodlum $2 \mathrm{mg}$} \\
\hline \multicolumn{2}{|l|}{ Total Carbohydrate $\mathrm{Ag}$} \\
\hline \multicolumn{2}{|l|}{ Dletary Flber $1 \mathrm{~g}$} \\
\hline \multicolumn{2}{|l|}{ Sugars $2 g$} \\
\hline \multicolumn{2}{|l|}{ Proteln 19 } \\
\hline \multicolumn{2}{|l|}{ Vltamin A } \\
\hline \multirow{2}{*}{\multicolumn{2}{|c|}{ 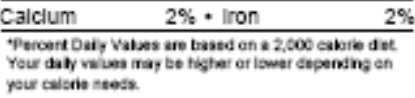 }} \\
\hline & \\
\hline Gwww.NutritionData.com & \\
\hline
\end{tabular}

\section{Why Buy Locally?}

The U.S. Department of Agriculture (USDA) estimates that the average farmers' market produce travels about $\mathbf{5 0}$ miles to its destination, compared to $\mathbf{2 , 0 0 0}$ miles for supermarket produce.

Buy locally and get these benefits:

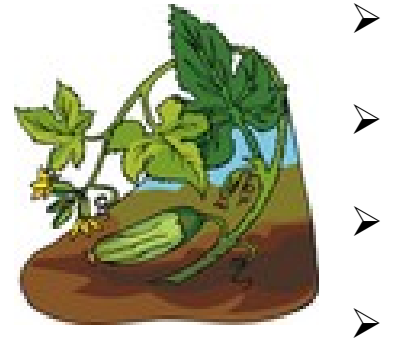

Freshness and good nutrition. Fruits and vegetables harvested in their peak have better flavor and nutritional characteristics.

Social/cultural. Helps the community to be aware of the importance of agriculture.

Environmental. Protects the natural resources such as green space, wildlife, water, air, and soil.

Economic. Promotes local labor force.

\section{Where Are Florida's summer squash harvested?}

Most of Florida's zucchini are grown in North Central Florida, while most of Florida's yellow squash are grown in west-Central and South Florida. Summer squash adapts well to the warm climate. They should be harvested before they are fully mature.

1. This document is FCS8880, one of a series of the Department of Family, Youth and Community Sciences, Florida Cooperative Extension Service, Institute of Food and Agricultural Sciences, University of Florida. First published: August 2009.Visit the EDIS Web site at http://edis.ifas.ufl.edu.

2. Claudia Peñuela, nutrition assistant-EFNEP, Department of Family, Youth and Community Sciences; Institute of Food and Agricultural Sciences; University of Florida; Gainesville, FL 32611. 


\section{When can you buy Florida summer squash?}

You can buy Florida Summer squash from September through June. This is ten months out of the year!

\begin{tabular}{|l|l|l|l|l|l|l|l|l|l|l|l|}
\hline JAN & FEB & MAR & APR & MAY & JUN & JUL & AUG & SEP & OCT & NOV & DEC \\
\hline
\end{tabular}

\section{Select}

$\checkmark$ Glossy deep green, slim, and cylindrical shaped zucchini.

$\checkmark$ Bright yellow, bottle-shaped or cylindrical shaped yellow squash.

$\checkmark$ Summer squash that are tender and firm with no soft spots.

$\checkmark$ Summer squash that are heavy for their size.

\section{Florida Fresh Summer Squash: From Market to Table}

\section{colorful Squash and Tomato Gratín}

2 cloves garlic, chopped

2 shallots, chopped

1 Tbsp chopped basil, or 1 tsp dried

$1 / 2$ tsp salt and $1 / 2$ tsp black pepper

2 medium yellow squash, thinly sliced

lengthwise

2 medium zucchini, thinly sliced lengthwise

3 medium tomatoes, thinly sliced

2 Tbsp grated Parmesan cheese

$1 / 4$ cup dry bread crumbs

Olive oil for drizzling

\section{Yield: 6 Servings}

1. Preheat oven to $400^{\circ} \mathrm{F}$. Lightly oil an 8 -inch square baking dish.

2. Spread the garlic, shallots, and basil in the bottom of the prepared dish. Add salt and pepper.

3. Slice the yellow squash, zucchini, and tomatoes in straight alternating layers, repeating until all the vegetables are used in the casserole.

4. Sprinkle the top with the cheese, then the bread crumbs.

Drizzle lightly with olive oil.

5. Bake for 20 to 25 minutes, until the vegetables are tender. Let stand for 5 minutes before serving.

Nutrition info per serving: Calories 95 cal; Total Fat 2g; Cholesterol 2mg; Sodium 266mg; Total Carbohydrates 18g; Protein 6g. Good source of Vitamin A and Vitamin C.

Adapted from: http://www.florida-agriculture.com/pubs/pubform/pdf/The Florida Chef Flavorful Seasons Cookbook.pdf

\section{Zucchini stir Fry}

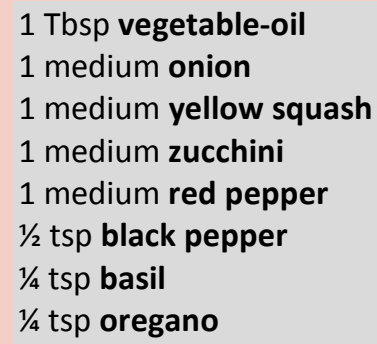

\section{Yield: 4 Servings}

1. Peel the onion. Cut it into thin slices.

2. Slice the yellow squash and zucchini into thin round pieces.

3. Chop the red pepper into small pieces.

4. Heat the oil in a frying pan. Add the onion slices, cook over medium heat for 1 minute.

5. Add the spices and stir a few times.

6. Cook for 3 to 5 minutes till vegetables are just tender.

Nutrition info per serving: Calories 70 cal; Total Fat 3.5g;

Cholesterol 0mg; Sodium 15mg; Total Carbohydrates 8g; Protein 2g. Good source of Vitamin C.

Adapted from: Pennsylvania Nutrition Education Network, Website Recipes, The Pennsylvania Nutrition Education Program; and http://recipefinder.nal.usda.gov/index.php?mode=display\&rec id=464 